\title{
Integrazione di nuove tecnologie di rilevamento e modellazione per l'analisi dei sistemi voltati a fascioni
}

\author{
Roberta Spallone \\ María Concepción López González \\ Marco Vitali
}

Abstract

Nel presente lavoro viene descritto il framework metodologico messo a punto per la realizzazione di un progetto internazionale di ricerca finalizzato all'analisi e salvaguardia del patrimonio architettonico. Tale progetto ha unito studiosi italiani e spagnoli nell'analisi, interpretazione e rappresentazione dei sistemi voltati a fascioni nel barocco torinese. Importanti maestri, come Guarini e Juvarra, ma anche figure meno note, fra Sei e Settecento hanno fatto uso di tali sistemi per coprire ambienti di media e grande dimensione. In particolare, nel centro storico di Torino sono stati riconosciuti tredici atri di palazzi, voltati a fascioni. Questi sono stati oggetto di rilievo, di acquisizioni metriche mediante laser scanner, di restituzioni grafiche bidimensionali e di ipotesi interpretative delle geometrie di progetto, facendo anche riferimento alla letteratura architettonica coeva, attraverso modellazione tridimensionale. L'integrazione fra la tecnica di rilevamento metrico e le modalità di modellazione bi e tri-dimensionale ha comportato la definizione di nuovi flussi di lavoro, finalizzati all'ottimizzazione dell'utilizzo dei dati. Da tali procedure scaturiscono nuove opportunità per la ricerca, come il confronto (metrico, ma ancora più interessante, geometrico) mediante la sovrapposizione dei modelli ideali di progetto e delle nuvole di punti. L'analisi e la comparazione dei sistemi voltati studiati consentiranno, infine, di evidenziare modelli formali e variazioni sul tema.

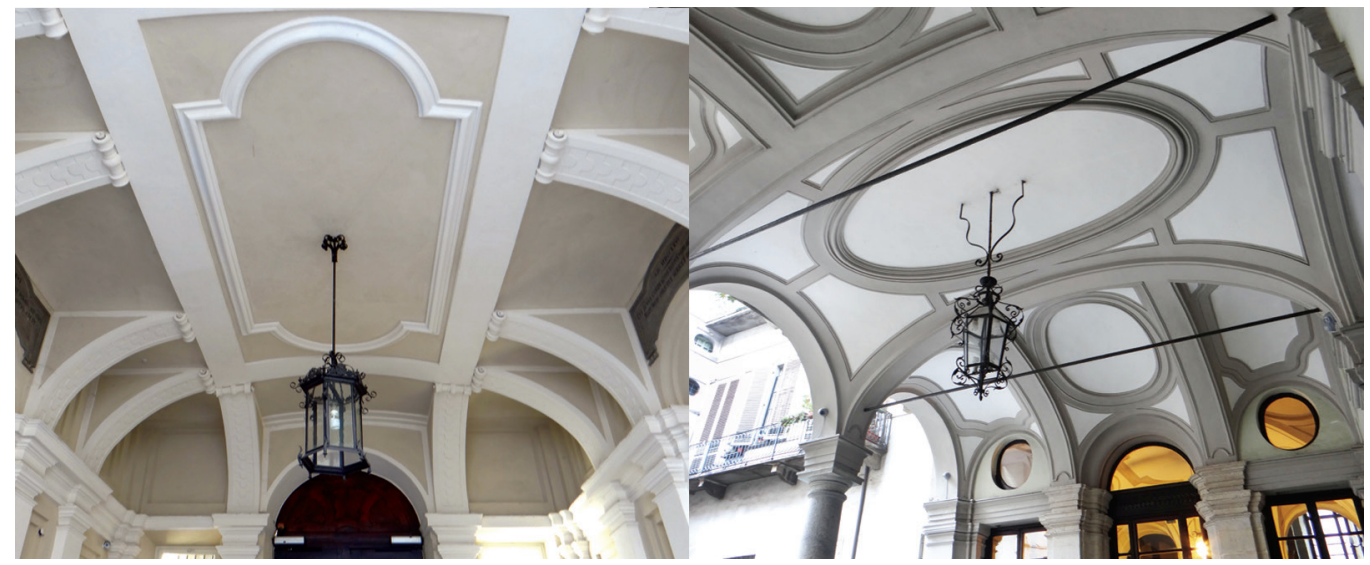




\section{Un progetto internazionale per l'analisi e la salvaguardia del patrimonio architettonico}

I sistemi voltati a fascioni costituiscono una delle principali coperture per ambienti di media e grande dimensione nei palazzi barocchi in Piemonte. I vantaggi offerti da tali sistemi sono ben sintetizzati da Guarino Guarini che, nell'Architettura civile, pubblicata postuma nel I737, per la prima volta ne parla come di una propria invenzione, da lui "posta in opera non senza molta varietà, e soddisfazione delle genti" [Guarini 1737, p. 189]. Nel suo discorso, infatti, le 'fascie', tracciate ortogonalmente o diagonalmente rispetto ai muri d'ambito, consentono di compartire la superficie di copertura in campi da riempire con volte di forme differenti, atte ad ospitare decorazioni dipinte (fig. I) [I].
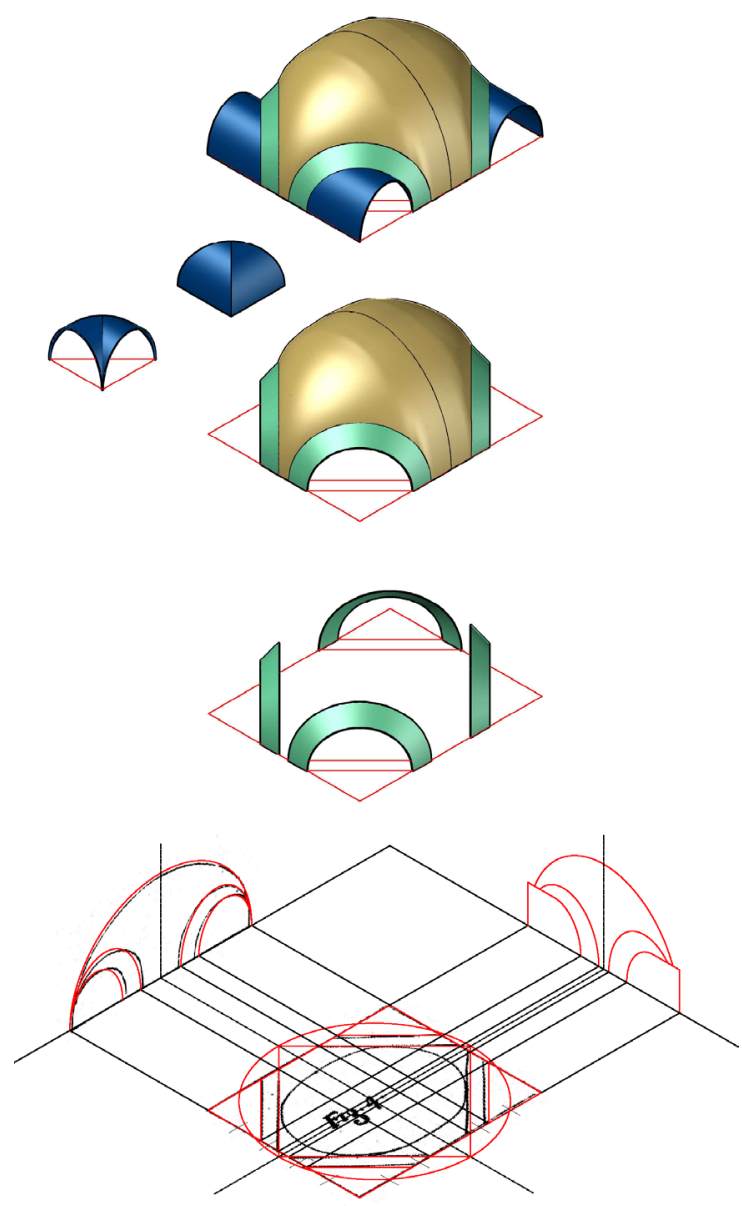

Non solo Guarini progetta e mette in opera tali tipi di volte, per esempio in Palazzo Carignano ( 1679): esse sono ampiamente utilizzate da Filippo Juvarra, che sembra prediligerle, nel secondo decennio del 1700, e da altre figure di rilievo nel panorama barocco come Amedeo di Castellamonte e Gian Giacomo Plantery, contemporanei, rispettivamente, di Guarini e di Juvarra. La presente ricerca, finalizzata all'indagine di tredici atri con volte a fascioni individuati nel centro storico di Torino (fig. 2), nasce da una collaborazione internazionale, favorita dal finanziamento da parte del Ministero della Scienza, dell'Innovazione e dell'Università di Spagna del progetto Nuevas tecnologías para el análisis y conservación del patrimonio arquitectónico. Questo ha consentito a Concepción López di unirsi al gruppo di ricerca coordinato da Roberta Spallone e Marco Vitali [2] che da alcuni anni conducono indagini sui sistemi voltati complessi in muratura laterizia nei palazzi barocchi del Piemonte, presso il Politecnico di Torino. 


\section{Volte a fasce tra letteratura architettonica e realizzazioni}

Le volte "a fascie", localmente definite anche "a fascioni", vengono introdotte, come si è visto, da Guarini nell'Architettura civile: nel Trattato III, al capo Vigesimosesto, Delle Volte, e varj modi di farle, egli dedica la Osservazione Nona e la Osservazione Decima alle volte "a fascie" e alle volte "a fascie piane". Nella Lastra XX del Trattato III vengono descritte in proiezioni ortogonali rispettivamente un modello di volta "a fascie" e un modello di volta "a fascie piane" (fig. 3).

Questa prima definizione geometrica e il relativo modello di riferimento trovano riscontro in realizzazioni sia coeve a Guarini, come nel caso della volta della Sala di Diana alla Reggia di Venaria (Amedeo di Castellamonte, I66 I- 1662), sia di pochi anni successive, tra la fine del Seicento, come nella volta dell'atrio di Palazzo Barolo (Gian Francesco Baroncelli, 1692) (fig. 4) e i primi anni del Settecento, come nelle coperture degli atri di Palazzo Galleani di Canelli e Barbaresco (Luigi Michele Barberis, 1709), [Vitali, Natta 2019], Palazzo Roero di Guarene (Carlo Giacinto Roero di Guarene, 17 I 0 circa) e Palazzo Martini di Cigala (Filippo Juvarra, 17|6).

Fig. 2. Mappa del centro storico di Torino con individuazıone degli atri barocchi voltati a fascion (elaborazione grafica di Marco Vitali).

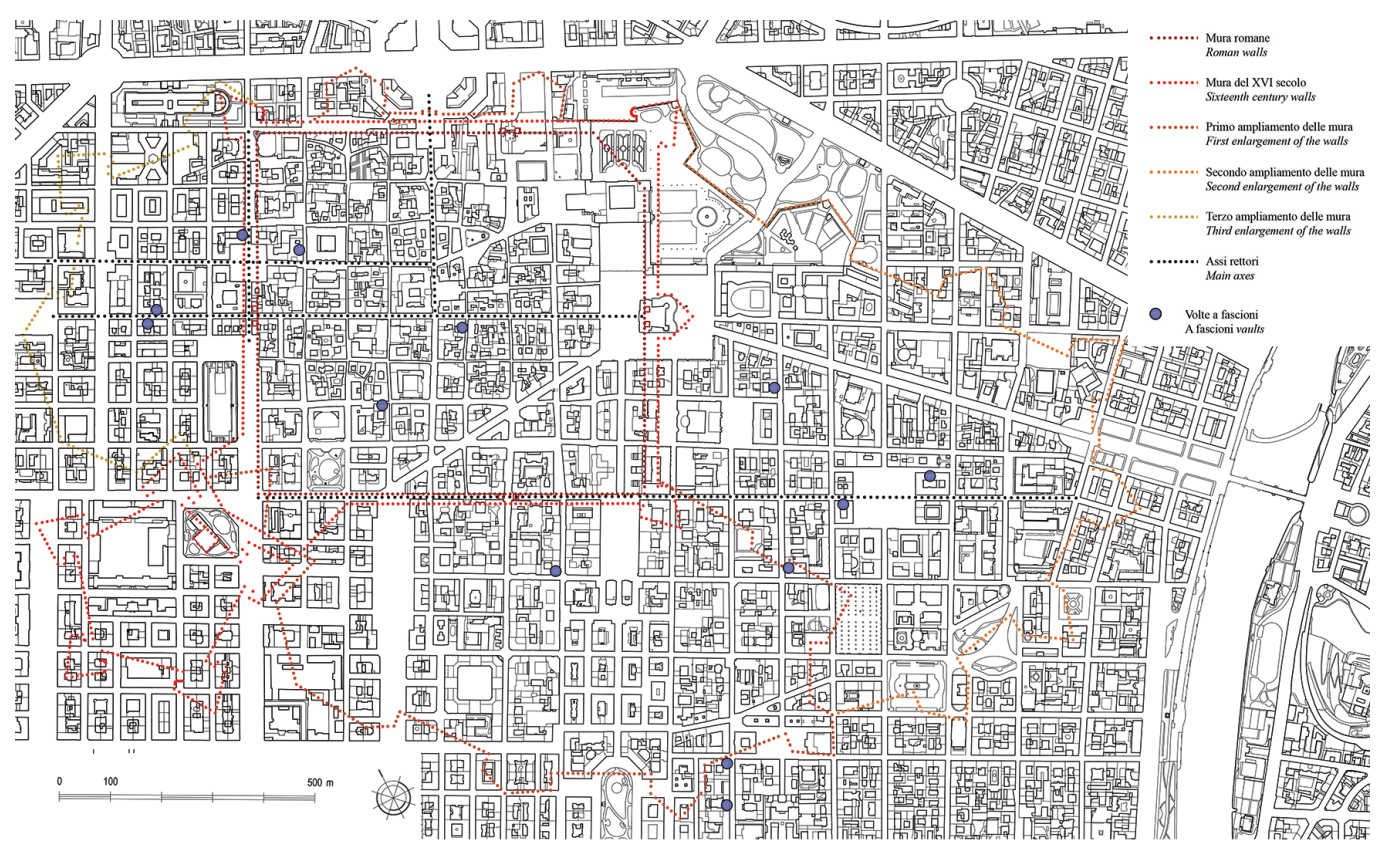

A far da tramite fra i contributi di taglio puramente teorico e quelli di stampo pratico, possono essere collocati gli studi sulle volte di Giovanni Curioni: nella Geometria pratica (I 868) egli definisce le volte 'a fascioni', riprendendo l'impostazione generale di Guarini, e aggiunge indicazioni relative alla genesi delle superfici generatrici degli arconi che suddividono l'ambiente, immaginando che "sul poligono da coprirsi con una di queste volte già insista l'intradosso di una volta la quale, a seconda della figura del detto poligono, può essere a botte, a conca, a padiglione, a botte con teste di padiglione, a schifo, a bacino" [Curioni I 868, pp. 288, 289]. Operando per tagli con piani verticali sulla superficie di riferimento, si ottengono gli arconi su cui si imposta la struttura geometrica della volta [Curioni I868], (fig. 3). Gli atri censiti che afferiscono a questo secondo modello di riferimento sembrano appartenere ad un periodo successivo, benché per la maggior parte di essi non vi siano attribuzioni e date certe. All'interno di questo gruppo possiamo riconoscere: atri voltati con fasce trasversali interrotte in corrispondenza della campata centrale come in Palazzo Capris di Cigliè (Gian Giacomo Plantery, I730), (fig. 5), nei palazzi in via Garibaldi 38 e via 
Garibaldi 53 [3]; atri coperti con intreccio di fasce continue e campi unitari, come nel palazzo in via Bogino 4, nel palazzo in via Carlo Alberto 36 e nel palazzo in via dei Mercanti 2; atri voltati con intreccio di fasce continue e campi con unghie, come in Palazzo Coardi di Carpenetto, in Palazzo Baroni di Tavigliano (Giovanni Pietro Baroni di Tavigliano), (fig. 6) e nel palazzo in via Carlo Alberto 40.

Sempre in seno alla cultura torinese, Giovanni Chevalley, nel suo Elementi di tecnica dell'architettura: materiali da costruzione e grosse strutture (1924) raccoglie una summa dei saperi costruttivi locali nell'ambito delle strutture voltate e arricchisce il quadro conoscitivo attraverso numerose tavole in cui indica le più consuete apparecchiature laterizie, la disposizione delle centine e gli sviluppi sul piano delle superfici intradossali.

Nella descrizione delle volte "a fascioni" egli riprende la definizione di Curioni e indica alcuni esempi costruiti, enfatizzandone le qualità spaziali [Chevalley 1924, p. 268-270]. (M.V.).

\section{Metodologie di rilevamento TLS applicate ai sistemi voltati}

II rilievo di dati metrici e geometrici dei sistemi voltati comporta una grande difficoltà insita nella doppia curvatura delle superfici che li compongono. L'uso di sistemi tradizionali di misurazione per mezzo di distanziometri laser o stazioni topografiche non è sufficiente, perché essi basano la loro efficacia sulla scelta di una serie di punti discrezionali della volta, ma non sulla sua intera superficie. I metodi di raccolta dati con l'utilizzo di laser scanner comportano un parziale superamento di questo problema. II laser scanner terrestre (TLS) è una tecnologia per la raccolta di dati metrici e geometrici che viene utilizzata dal 200 I [Rodriguez et al., 2012, p. 264]. Questo dispositivo esegue una scansione puntuale sulle superfici battute dal raggio laser, creando una nuvola di punti che discretizza la superficie oggetto di rilievo [Ramos et al. 20 I5, p. 329], (fig. 7).

Fig. 3. Guarino Guarini, Architettura civile, 1737 Trattato III, Lastra XX: volte "a fascie" e volte "a fascie piane" (a sinistra). Giovanni Curioni, Geometria Pratica,

1868, Tavola XIII: volta "a fascioni" su pianta rettangolare (a destra).
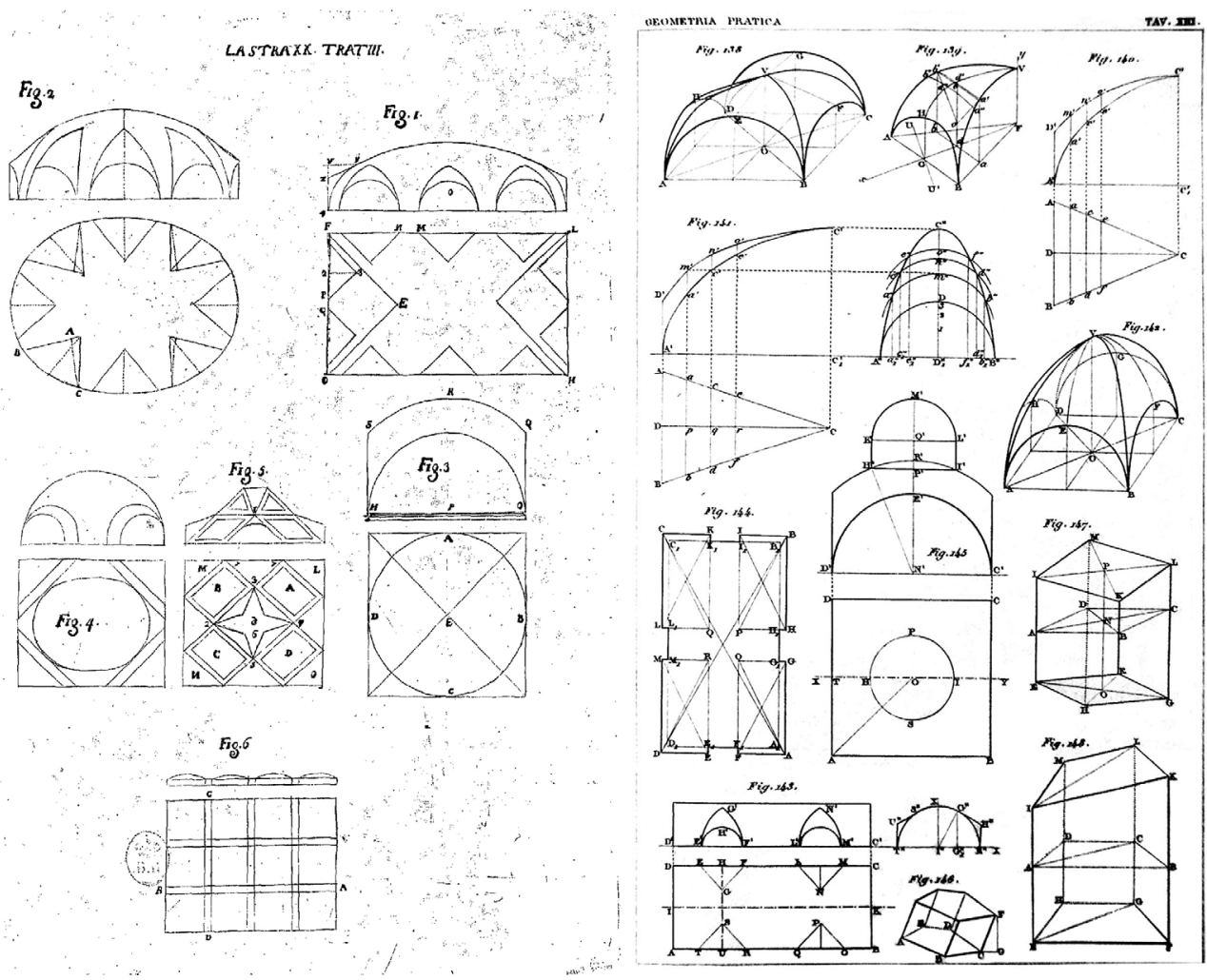
Fig. 4. Volta a fascioni nell'atrio di Palazzo Barolo (foto di Marco Vitali).

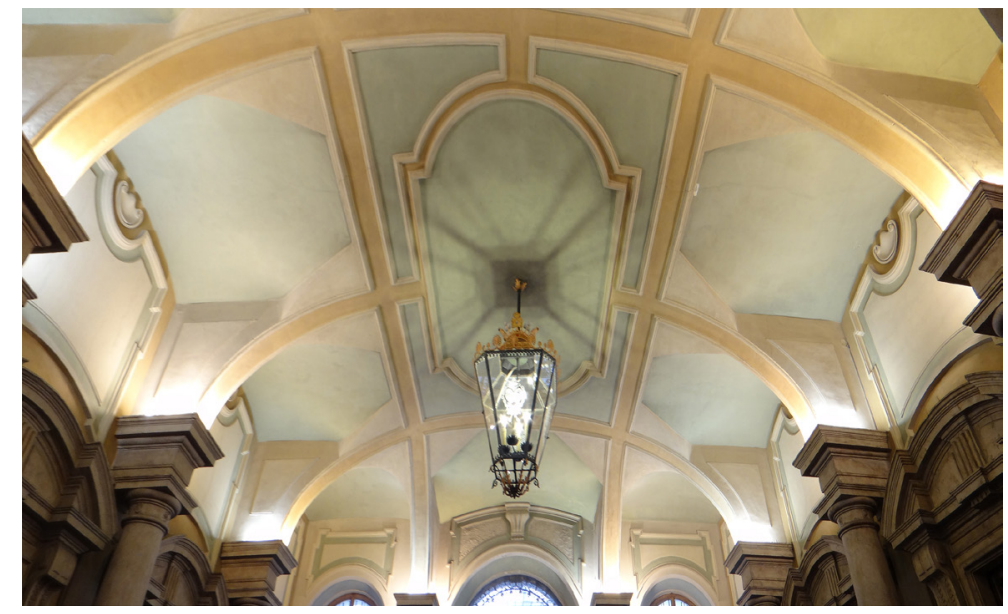

Tuttavia, è necessario tenere in considerazione che le caratteristiche di uso offerte da ogni tipo di laser scanner influenzano i risultati ottenuti, così come le prerogative della superficie da rilevare. Questi varieranno a seconda del colore, della rugosità e della riflettanza della superficie [Pfeifer et al. 2008, p. 330]. Un altro fattore che influenza i risultati è la distanza alla quale lo scanner viene posizionato, poiché maggiore è la distanza tra la stazione e la superficie da rilevare e minore è l'intensità di ritorno [Mechelke, Kersten, Lindstaedt 2007, p. 320]. Tutti questi fattori sono solitamente presenti nei casi di superfici voltate e quindi si

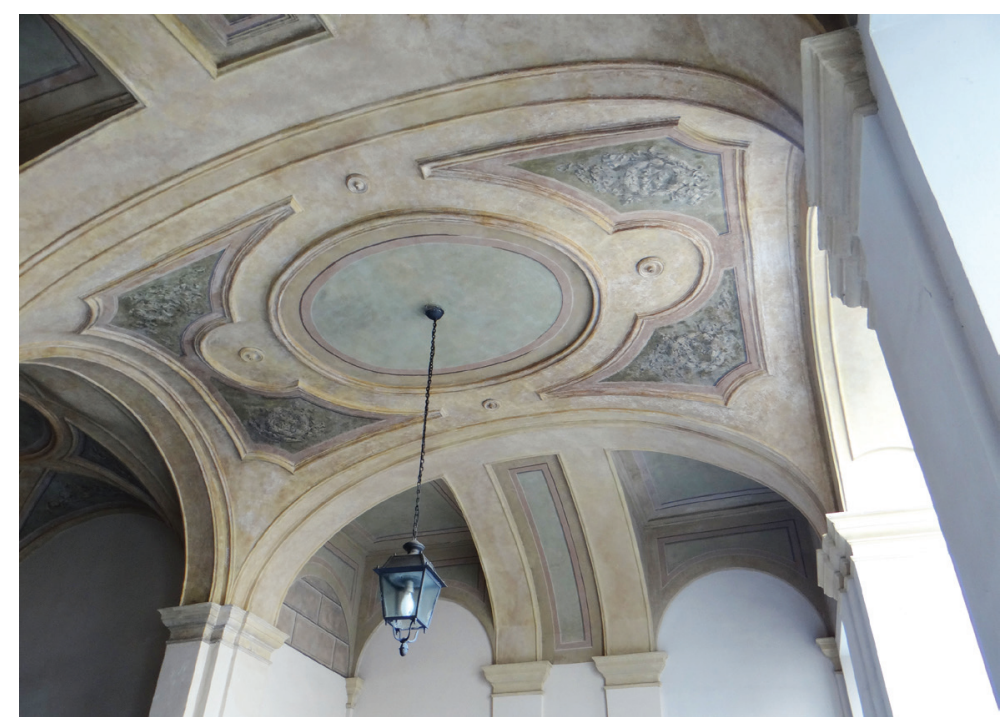

deve utilizzare un dispositivo con le giuste caratteristiche. Per questo studio è stato utilizzato il modello Focus-130-3D di Faro che permette di assegnare ad ogni punto il suo colore. Dopo la scansione, infatti, scatta una serie di fotografie che serviranno ad implementare il colore nella nuvola di punti. Anche la distanza di acquisizione risulta adeguata, poiché con questo modello di strumento si ottiene una buona densità di punti fino a distanze di $50 \mathrm{~m}$. Un aspetto importante da considerare è l'angolo di incidenza del raggio, che nel caso delle volte varia lungo tutta la superficie. Per risolvere questo problema, sono state predisposte 


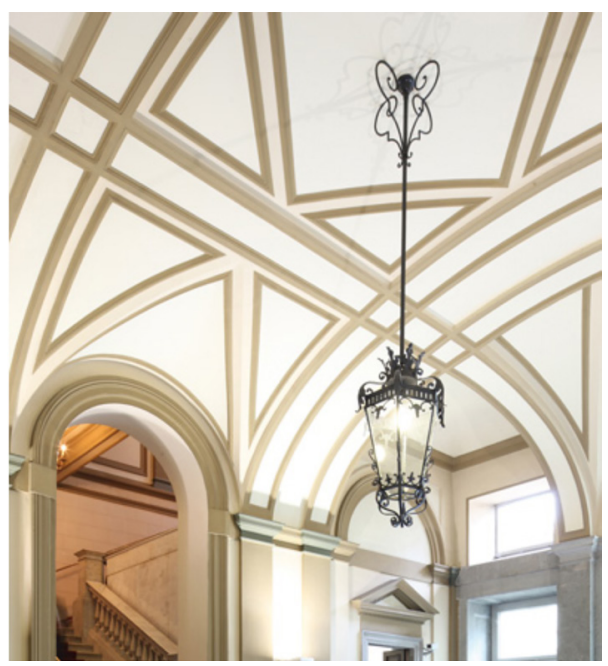

stazioni di scansione con angoli di incidenza diversi e disposte sufficientemente vicine da consentire la sovrapposizione dei dati al fine di ottenere risultati più affidabili. D'altra parte, le volte a fascioni presentano punti ciechi dovuti alle ombre degli archi che scandiscono la volta. In questi casi è necessario localizzare tante stazioni quante sono le porzioni del sistema voltato. Tutto ciò richiede una precedente programmazione della campagna di rilievo che garantisca la scansione della totalità delle superfici con una densità di punti sufficiente e la sovrapposizione necessaria per ottenere risultati rigorosi (fig. 8). II trattamento della nuvola di punti è stato realizzato con il programma associato al modello di scanner, Scene, versione 19, che fornisce risultati rapidi e ottimali. (M.C.L.G.).
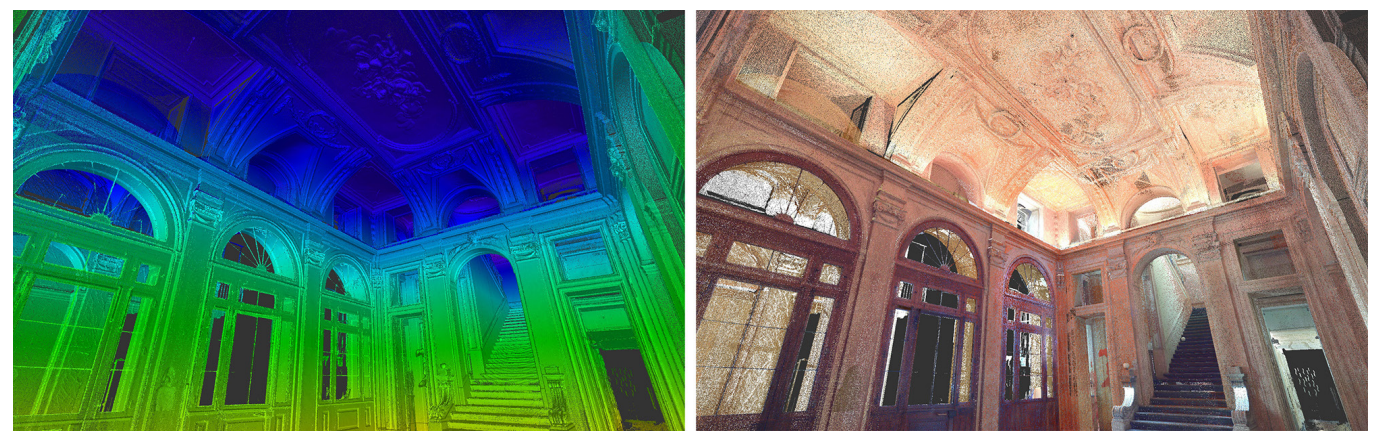

\section{Modellazione digitale bi e tridimensionale fra ideazione e costruzione}

Le metodologie di restituzione grafica e di modellazione tridimensionale dei sistemi voltati messe a punto in precedenti ricerche [Spallone, Vitali 20 17] sono state attualizzate e modificate in funzione delle differenti tecniche di acquisizione metrica e della diversa struttura concettuale del sistema a fascioni.

I due prodotti grafici principali consistono in pianta e sezioni in scala 1:50 dell'intero invaso, esito delle operazioni di rilevamento metrico e analisi interpretativa delle consistenze architettoniche, e nel modello digitale tridimensionale, ricollegabile alla fase di ideazione formale del sistema voltato, informato dai riferimenti alla letteratura architettonica coeva e alle fonti archivistiche. 
Fig. 8. Schema di programmazione del processo di scansione de sistema voltato dell'atrio di Palazzo Coardi di Carpenetto (diseono María Concepción López González).
Fig. 9. Volta a fascioni con voltine indipendent nell'atrio di Palazzo Martini di Cigala (foto di Marco Vitali).

Fig. 10.Volta a fascioni generata da una superficie a conca nell'atrio di Palazzo Coardi di Carpenetto (foto di Marco Vitali).
I disegni bidimensionali assumono ora, come base per il tracciamento, sezioni con piani orizzontali e verticali della nuvola di punti generata dalla scansione laser. La selezione dei piani di taglio e dei piani di riferimento della nuvola di punti per costruire le sezioni verticali più significative è un'operazione concettualmente complessa che costringe il disegnatore a traslare o ruotare il piano di sezione, in modo da intersecare gli elementi più significativi, come

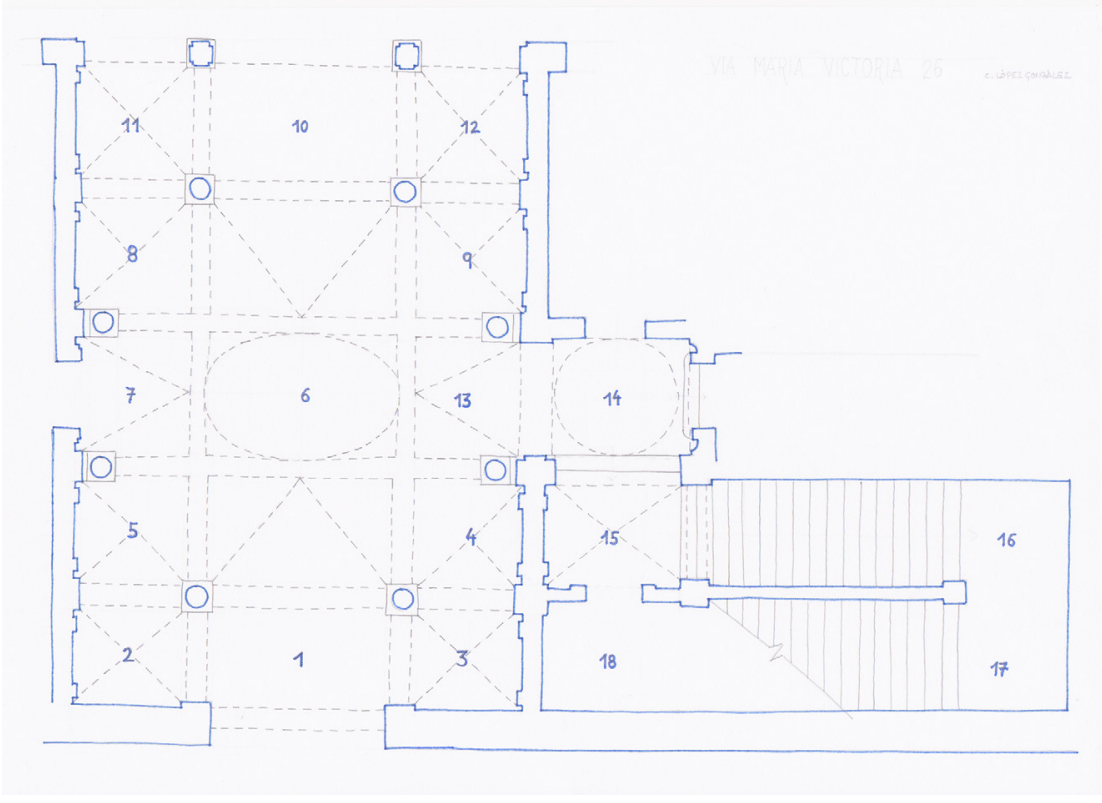

le chiavi di ogni volta, e di evitare scorci in elevazione dietro il piano di taglio. II passaggio dalla nuvola di punti al disegno vettoriale genera ulteriori questioni legate alla necessità di individuare le sequenze di punti che delineano elementi geometricamente significativi: spigoli, intersezioni tra superfici, linee di imposta e di chiave della volta. La scala di riduzione scelta per la produzione dei disegni può suggerire la distanza minima per la selezione dei punti, ma ciò non è sufficiente quando ci si trovi di fronte a un'architettura storica caratterizzata da ordini architettonici e apparati decorativi il cui disegno rigoroso garantisce riconoscibilità e corretta interpretazione.

Per quanto riguarda la modellazione digitale ricostruttiva dell'idea progettuale si pone la necessità di ripristinare le simmetrie e ricondurre le sezioni a geometrie elementari.

II metodo di analisi, scomposizione e ricomposizione si fonda sulle indicazioni guariniane, circa il "modo di disegnare le Volte" [Guarini I737, p. I88], che delinea una sequenza, dalla compartimentazione delle piante mediante le fasce, al riempimento dei campi liberi con voltine autonome.
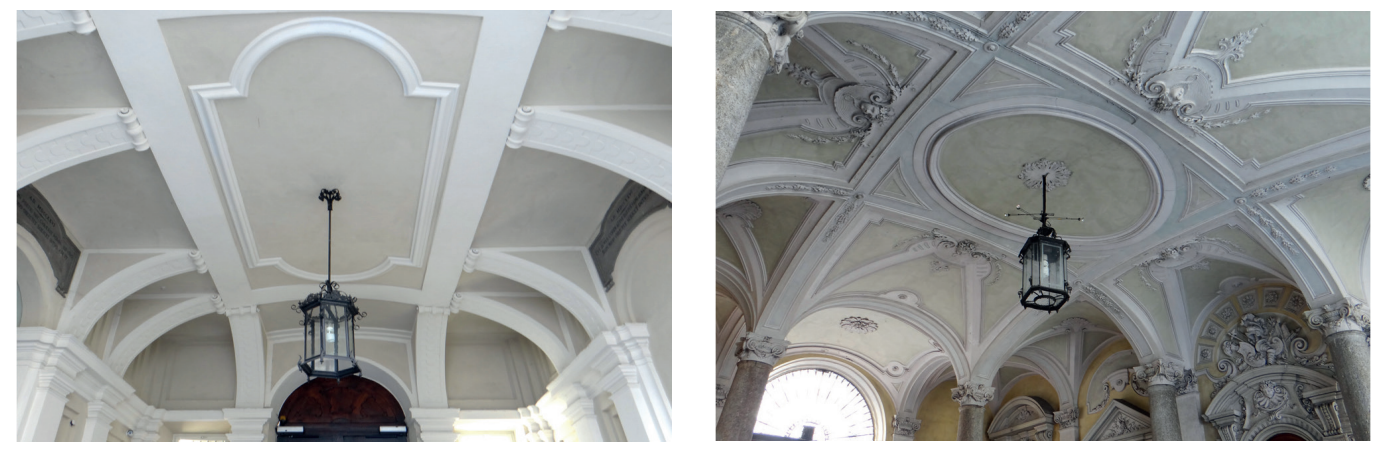
Fig. I I. Palazzo Martini di Cigala, scomposizione dei modelli interpretativ di volte a fascioni con voltine indipendenti (modellazione digitale di Roberta Spallone).

\section{Fig. 12. Palazzo}

Coardi di Carpenetto

scomposizione del

molte a fascioni genivi di

(modellapione digtanca

(modellazione digitale di
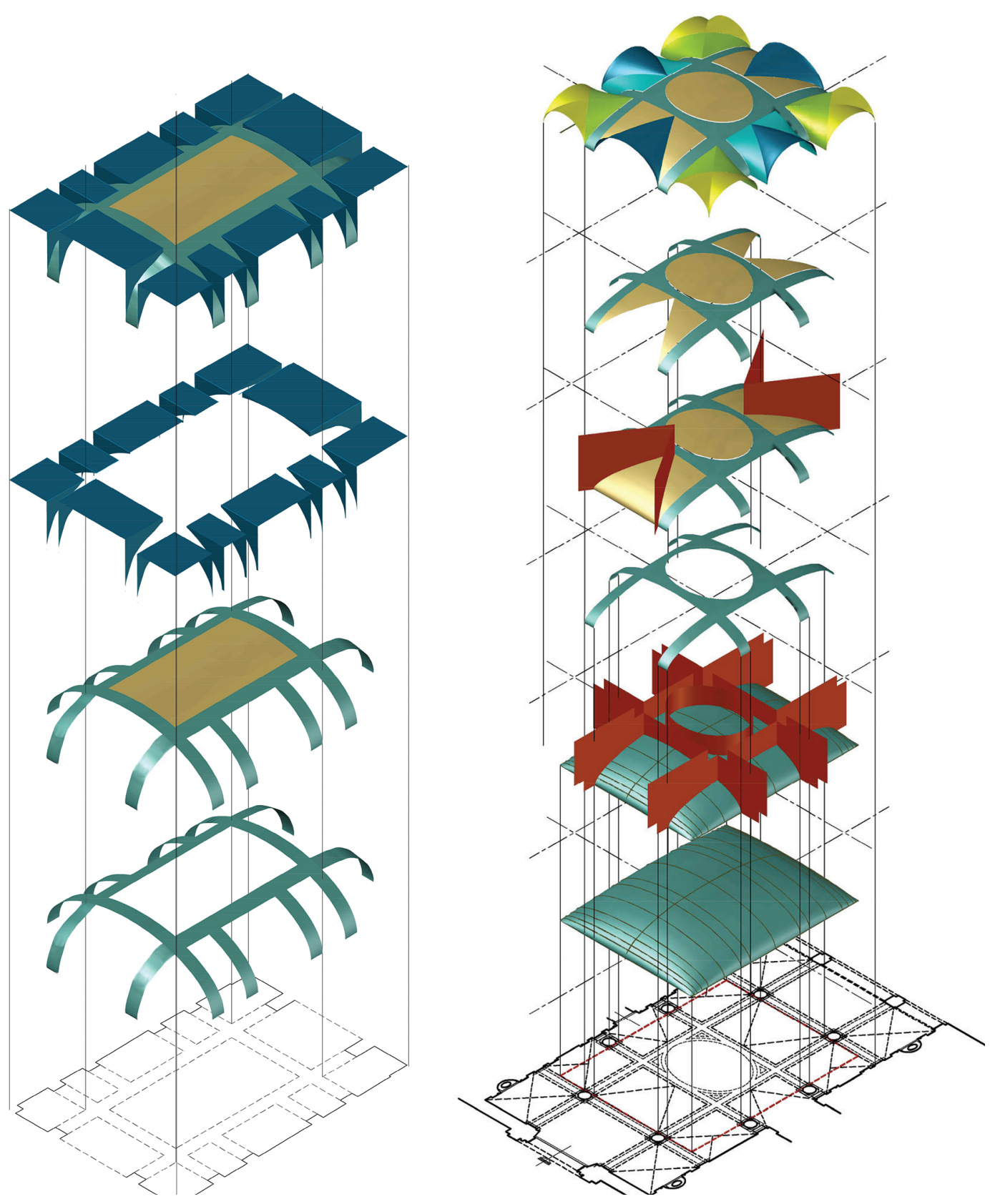
Non in tutti i casi analizzati, però, le voltine sono geometricamente indipendenti dagli archi che le delimitano (fig. 9). In questi ultimi, gli archi possono essere pensati come esito del taglio di una volta a conca, la cui superficie è conservata, generalmente almeno nel campo centrale della volta (fig. 10). Tali archi, anziché cilindrici o tronco-conici, come nei casi di volte a fascioni con voltine indipendenti, assumono sezioni longitudinali e trasversali curve e variabili in continuo. La scomposizione dei modelli, nel primo caso inizia dagli archi di partizione della pianta, cui seguono i completamenti con le voltine (fig. I I). Nel secondo caso, la volta principale a conca viene tagliata con coppie di piani paralleli, per generare gli archi, mentre alcune porzioni di essa vengono mantenute e i campi liberi, spesso agli angoli, sono completati da voltine indipendenti (fig. I2). (R.S.).

\title{
Conclusioni
}

II presente contributo delinea il frame-work metodologico messo a punto per l'indagine metrica e la elaborazione dei dati conoscitivi nella ricerca sui sistemi voltati a fascioni nel barocco torinese.

L'integrazione fra la tecnica di rilevamento metrico mediante laser scanning e le modalità di modellazione bi-dimensionale, riferita alle architetture indagate nella loro attuale fisionomia, e tridimensionale, connessa a modelli geometrici di riferimento per la ricostruzione filologica dell'idea progettuale, comporta, come si è visto, la definizione di nuovi criteri di lavoro, finalizzati all'ottimizzazione dell'utilizzo dei dati. Da tali procedure scaturiscono nuove opportunità per la ricerca, come il confronto (metrico, ma ancora più interessante, geometrico) mediante la sovrapposizione dei modelli ideali di progetto e delle nuvole di punti. Gli scostamenti fra i due prodotti digitali non solo riveleranno le deformazioni, i cedimenti, le trasformazioni che fanno parte della vita stessa del manufatto, ma, soprattutto, forniranno nuovi spunti per le ipotesi sugli adattamenti, le tecniche di centinatura e di posa messi a punto in cantiere, ossia potranno contribuire alla comprensione delle relazioni tra ideazione e costruzione. L'analisi e la comparazione dei sistemi voltati indagati, che si intendono raccogliere in un volume monografico, consentiranno, infine, di evidenziare modelli formali e variazioni sul tema.

\section{Note}

[I] La ricerca presentata è l'esito del lavoro congiunto dei tre autori. I paragrafi Un progetto internazionale per l'analisi e la salvaguardia del patrimonio architettonico e Conclusioni sono stati redatti congiuntamente; il paragrafo Volte a fasce tra letteratura architettonica e realizzazioni da Marco Vitali; il paragrafo Metodologie di rilevamento TLS applicate ai sistemi voltati da María Concepción López González, il paragrafo Modellazione digitale bi e tridimensionale fra ideazione e costruzione da Roberta Spallone.

[2] Fanno parte del gruppo di ricerca gli architetti Giulia Bertola (assegnista presso MODLab Arch, Politecnico di Torino), Fabrizio Natta (borsista presso DAD, Politecnico di Torino) e Francesca Ronco (assegnista presso MODLab Design, Politecnico di Torino)

[3] Questi due atri in via Garibaldi sono sicuramente successivi al rettilineamento e allargamento della via con conseguente riplasmazione degli edifici prospicienti, all'epoca Contrada di Dora Grossa, effettuato a partire dalla fine degli anni '30 del Settecento.

\author{
Riferimenti bibliografici \\ Chevalley Giovanni (1924). Elementi di tecnica dell'architettura: materiali da costruzioni e grosse strutture. Torino: Pasta. \\ Curioni Giovanni ( 868$)$. Geometria pratica applicata all'arte del costruttore. Torino: Negro.
}

Guarino Guarini (1968). Architettura Civile. Introduzione di Nino Carboneri. Note e appendice a cura di Bianca Tavassi La Greca. Milano: II Polifilo (I ed. 1737).

Mechelke Klaus, Kersten Thomas P., Lindstaedt Maren (2007). Comparative investigations into the accuracy behaviour of the new generation of Terrestrial Laser Scanning systems. In Optical 3-D Measurement Techniques VIII, I (8I 3), pp. 3 I 9-327.

Pfeifer Norbert, Dorninger Peter, Haring Alexander, Hongchao Fan (2008). Investigating terrestrial laser scanning intensity data: quality and functional relations. In Optical 3-D Measurement Techniques VIII, I (8I 3), pp. 328-337. 
Piccoli Edoardo (1999). Strutture voltate composte nell'architettura civile piemontese del XVIII secolo: le volte planteriane. In Palladio, 3, 1999, pp. 87-100.

Piccoli Edoardo (200 I). Le strutture voltate nell'architettura civile a Torino (I660- I720). In Dardanello, Giuseppe (a cura di). Sperimentare l'architettura: Guarini, Juvarra, Alfieri, Borra e Vittone. Torino: Fondazione CRT, pp. 38-96.

Rodriguez Caballero Emilio, Chamizo Sonia, Afana Ashraf et al. (2012). Extracción automática de MDT a partir de datos procedentes de láser escáner (Espada). XI Reunión Nacional de Geomorfología Solsona. 20-24 de septiembre 20 I0. Santander: Ed. Universidad de Cantabria, pp. 263-266.

Ramos Luis, Marchamalo Miguel, Rejas, Juan Gregorio, Martínez R. (20I5). Aplicación del Láser Escáner Terrestre (TLS) a la modelización de estructuras: precisión, exactitud y diseño de la adquisición de datos en casos reales. In Informes de la Construcción, 67(538): e074, pp. I-9.

Spallone Roberta, Vitali Marco (20 17). Volte stellari e Planteriane negli atri barocchi in Torino. Star-shaped and Planterian Vaults in the Baroque Atria of Turin. Ariccia: Aracne.

Vitali Marco (20 | 8). Astrazione geometrica e modellazione tridimensionale per la definizione di una grammatica spaziale delle 'volte a fascioni' / Geometric abstraction and three-dimensional modeling for the definition of a spatial grammar of the 'a fascioni' vaults. In Salerno Rossella (a cura di). Rappresentazione/Materiale/lmmateriale | Drawing as (in)tangible representation. Atti del $40^{\circ}$ Convegno internazionale dei Docenti delle discipline della Rappresentazione. Milano 13- I5 settembre 20 I8. Roma: Gangemi Editore, pp. 86।-870

Vitali Marco, Natta Fabrizio (2019). Digital Survey and 3D Geometric Interpretation of Complex Vaulted Systems. Palazzo Valperga Galleani di Barbaresco in Turin. In Metrology for Archaeology and Cultural Heritage (MetroArchaeo 20 I9) - Proceedings. Budapest: IMEKO, pp. 205-210.

\section{Autori}

Roberta Spallone, Politecnico di Torino, roberta.spallone@polito.it

María Concepción López González, Universitat Politècnica de València, mlopezg@ega.upv.es Marco Vitali, Politecnico di Torino, marco.vitali@polito.it

Per citare questo capitolo: Spallone Roberta, López González María Concepción, Vitali Marco (2020). Integrazione di nuove tecnologie di rilevamento e modellazione per l'analisi dei sistemi voltati a fascioni /lntegration of new survey and modeling technologies aimed at the analysis of banded vaulted systems. In Arena A., Arena M., Brandolino R.G., Colistra D., Ginex G., Mediati D., Nucifora S., Raffa P. (a cura di). Connettere. Un disegno per annodare e tessere. Atti del $42^{\circ}$ Convegno Internazionale dei Docenti delle Discipline della Rappresentazione/Connecting. Drawing for weaving relationships. Proceedings of the 42th International Conference of Representation Disciplines Teachers. Milano: FrancoAngeli, pp. 27I 6-2735. 


\title{
Integration of New Survey and Modeling Technologies Aimed at the Analysis of Banded Vaulted Systems
}

\author{
Roberta Spallone \\ María Concepción López González \\ Marco Vitali
}

\section{Abstract}

This paper describes the methodological framework developed for the realization of an international research project aimed at the analysis and preservation of Architectural Heritage. This project has brought together Italian and Spanish scholars in the analysis, interpretation and representation of banded vaulted systems in Baroque Turin. Important masters, such as Guarini and Juvarra, but also lesser known figures, between 17 th and I 8th centuries made use of such systems to cover medium and large rooms. In particular, in Turin historic center, eleven atria of buildings, covered by banded vaults, have been recognized. These atria were the subject of survey, laser scanner acquisition, two-dimensional graphic representations, and interpretative hypotheses of the design's geometries, also referring to coeval architectural literature, through three-dimensional modelling.

The integration between metric survey technique and two and three-dimensional modelling methods led to the definition of new workflows, aimed at optimizing the use of data. From these procedures new opportunities for research arise, such as the comparison (metric, but even more interesting, geometric) through the superimposition of design ideal models and point clouds. Finally, the analysis and comparison of the studied vaulted systems will allow to highlight shape patterns and variations on the theme.

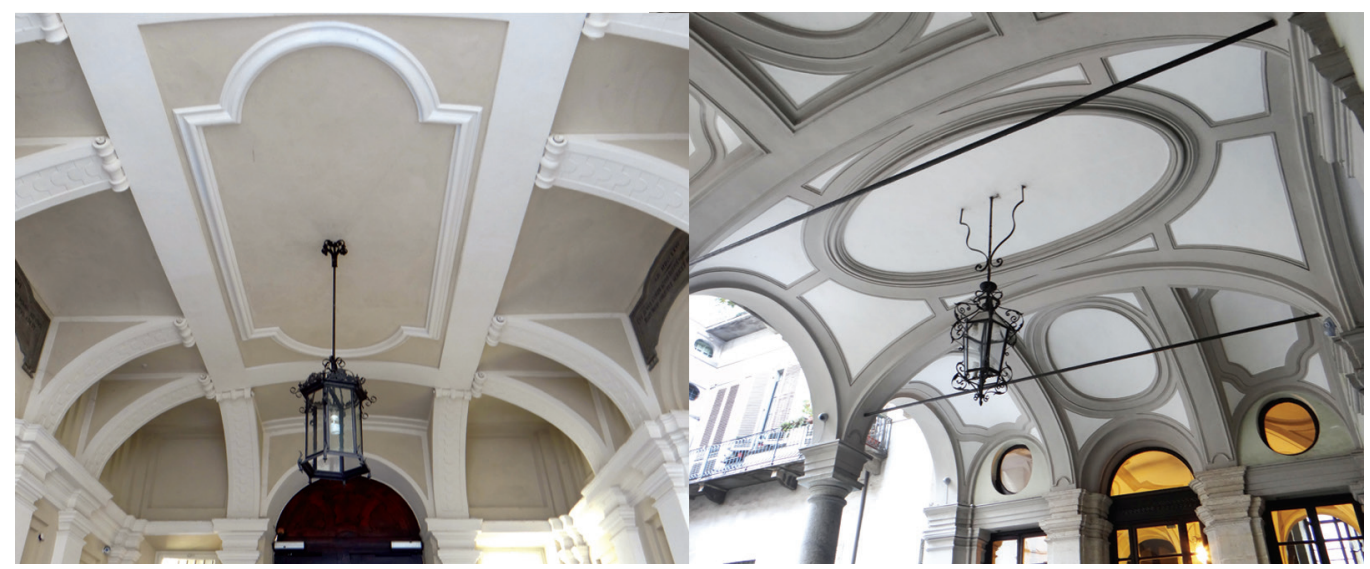




\section{An international project for the analysis and preservation of the architectural heritage}

The banded (in Italian 'a fascioni') vaulted systems are one of the main coverings for medium and large sized rooms of Baroque palaces in Piedmont. The advantages offered by such systems are well summarized by Guarino Guarini [I]. In the Architettura civile (published posthumously in 1737) for the first time he speaks of this kind of vaults as an invention of his own, which he "put in place with much variety, and satisfaction of the people" [Guarini I737, p. I89]. Indeed, in his reasoning, the 'fascie', traced orthogonally or diagonally to the perimeter walls, allow the roof surface to be divided into fields to be filled with vaults of different shapes, suitable for painted decorations (fig. I).
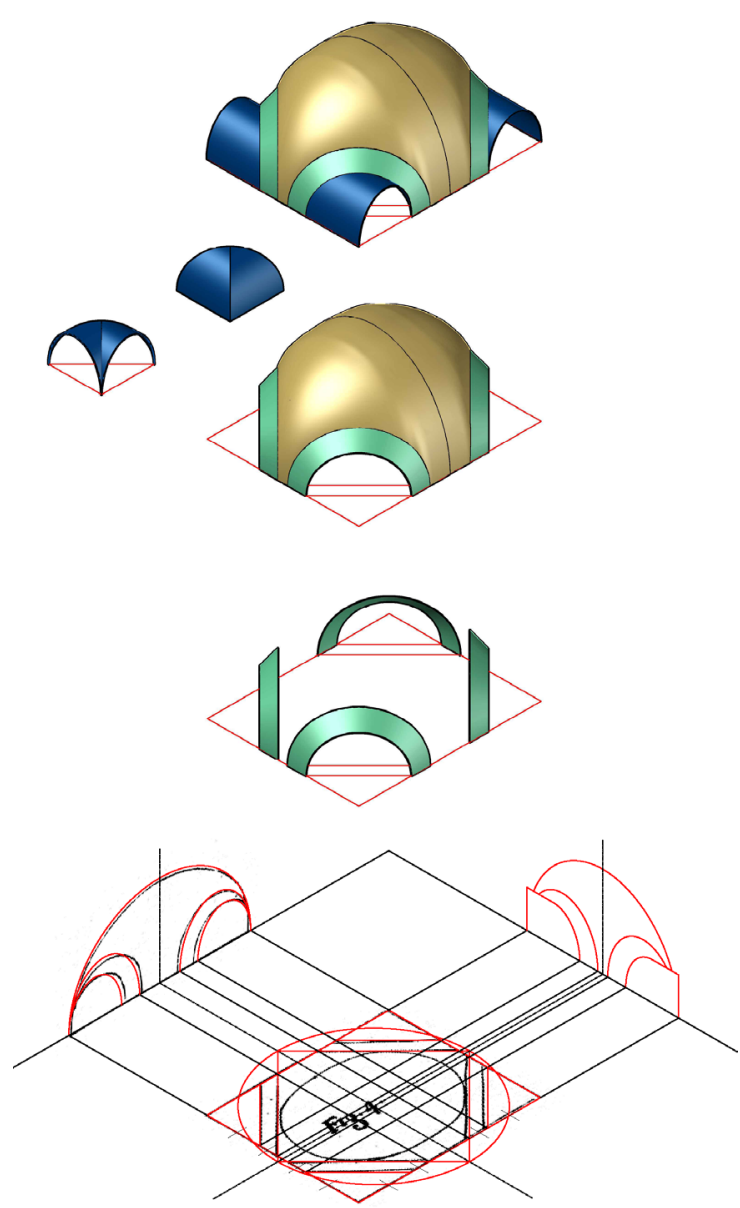

Guarini is not the only one who designs and implements such types of vaults, for example in Palazzo Carignano (1679): they were widely used by Filippo Juvarra, who seemed to prefer them, in the second decade of the 1700s, and by other important figures on the Baroque scene such as Amedeo di Castellamonte and Gian Giacomo Plantery, contemporaries, respectively, of Guarini and Juvarra.

The present research, aimed at the investigation of eleven atria with banded vaults identified in the historical centre of Turin (fig. 2), is the result of an international collaboration, favoured by the funding of the project Nuevas tecnologías para el análisis y conservación del patrimonio arquitectónico by the Ministry of Science, Innovation and the University of Spain. This allowed Concepción López to join the research group coordinated by Roberta Spallone and Marco Vitali [2], who for some years now have been conducting investigations into the complex brick vaulted systems in the baroque palaces of Piedmont, at the Politecnico di Torino. 


\section{Banded vaults between architectural literature and realizations}

Banded vaults, locally also called 'a fascioni', are introduced, as we have seen, by Guarini in his Architettura civile: in the Trattato III, capo Vigesimosesto, Delle Volte, e varj modi di farle, he dedicates the Ninth and Tenth Observation to the banded (a fascie) and the flat banded (a fascie piane) vaults. In the Plate $X X$, orthogonal projections describe, respectively, a model of a fascie vault and a model of a 'a fascie piane' vault (fig. 3).

This first geometrical definition and the relative reference model are found in buildings both contemporary to Guarini, as in the case of the vault of the Sala di Diana at the Reggia di Venaria (Amedeo di Castellamonte, 1661-1662), and a few years later, between the end of the seventeenth century, as in the vault of the atrium of Palazzo Barolo (Gian Francesco Baroncelli, 1692) (fig. 4) and the early eighteenth century, as in the roofing of the atria of Palazzo Galleani di Canelli e Barbaresco (Luigi Michele Barberis, 1709) [Vitali, Natta 2019], Palazzo Roero di Guarene (Carlo Giacinto Roero di Guarene, c. 17I0) and Palazzo Martini di Cigala (Filippo Juvarra, 17|6).

Fig. 2. Map of historic city center of Turin and localization of banded vaults Baroque atria grapfic elaboration by Marco Vitali).

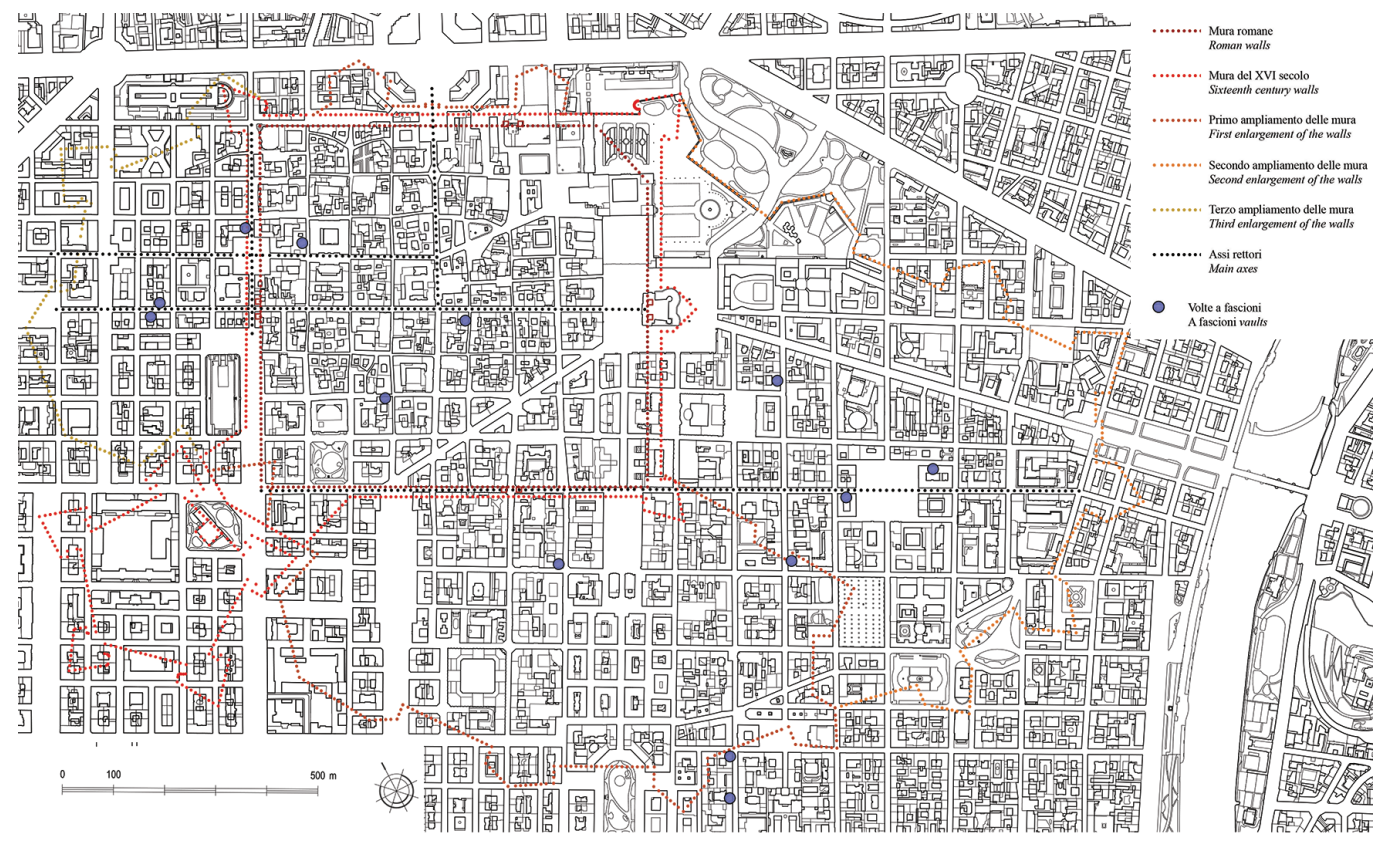

The studies by Giovanni Curioni on vaults can be placed between the purely theoretical and practical contributions. In his Geometria pratica (1868) he defines the banded vaults, taking up Guarini's general approach, and adds indications relative to the genesis of the generating surfaces of the arches that divide the room, imagining that "on the polygon to be covered with one of these vaults already insists the intrados of a vault which, depending on the figure of the said polygon, can be a barrel, a shell-like, a cloister, a barrel with cloister heads vault, a dome" [Curioni 1868, pp. 288, 289]. Working with cuts by vertical planes on the main surface, the arches on which the geometric structure of the vault is set are obtained [Curioni 1868, pp. 288, 289] (fig. 3). The atria surveyed that belong to this second reference model seem to belong to a later period, although for most of them there are no certain attributions and dates. Within this group we can recognize: vaulted atria with transversal bands interrupted in correspondence of the central span, as in Palazzo Capris di Cigliè (Gian Giacomo Plantery, 1730) (fig. 5), in the buildings in via Garibaldi 38, and via Garibaldi 53 [3]; atria covered with interlaced continuous bands and uniform fields, as in the building in 
via Bogino 4, in the building in via Carlo Alberto 36, and in the building in via dei Mercanti 2; vaulted atria with interlaced continuous bands and axial fields with groins, as in Palazzo Coardi di Carpenetto, in Palazzo Baroni di Tavigliano (Giovanni Pietro Baroni di Tavigliano) (fig. 6) and in the building in via Carlo Alberto 40.

Still within Turin's culture, Giovanni Chevalley, in his Elementi di tecnica dell'architettura: materiali da costruzione e grandi strutture (1924) collects a summa of local building knowledge in the field of vaulted structures and enriches the cognitive frame through numerous plates in which he indicates the most usual brickwork equipment, the arrangement of the ribs and the developments in terms of intrados surfaces.

In the description of the banded vaults he takes up the definition by Curioni and indicates some constructed examples, emphasizing their spatial qualities [Chevalley 1924, p. 268-270]. (M.V.).

\section{TLS survey methods applied to vaulted systems}

The survey of metric and geometric data of vaulted systems involves a great difficulty inherent in the double curvature of the surfaces that compose them. The use of traditional measurement systems by means of laser distance meters or topographic stations is not sufficient, because they base their effectiveness on the choice of a series of discretionary points of the vault, but not on its entire surface. Data collection methods using laser scanners will partially overcome this problem. The terrestrial laser scanner (TLS) is a technology for collecting metric and geometric data that has been used since 200 I [Rodriguez et al. 20 I2, p. 264]. This device performs a scan of surfaces beaten by the laser beam, creating a point cloud that discretizes the vaulted surface [Ramos et al. 20 I 5, p. 329] (fig. 7).

However, it is necessary to take into account that the characteristics of use offered by each type of laser scanner affect the results obtained, as well as the prerogatives of the surface to
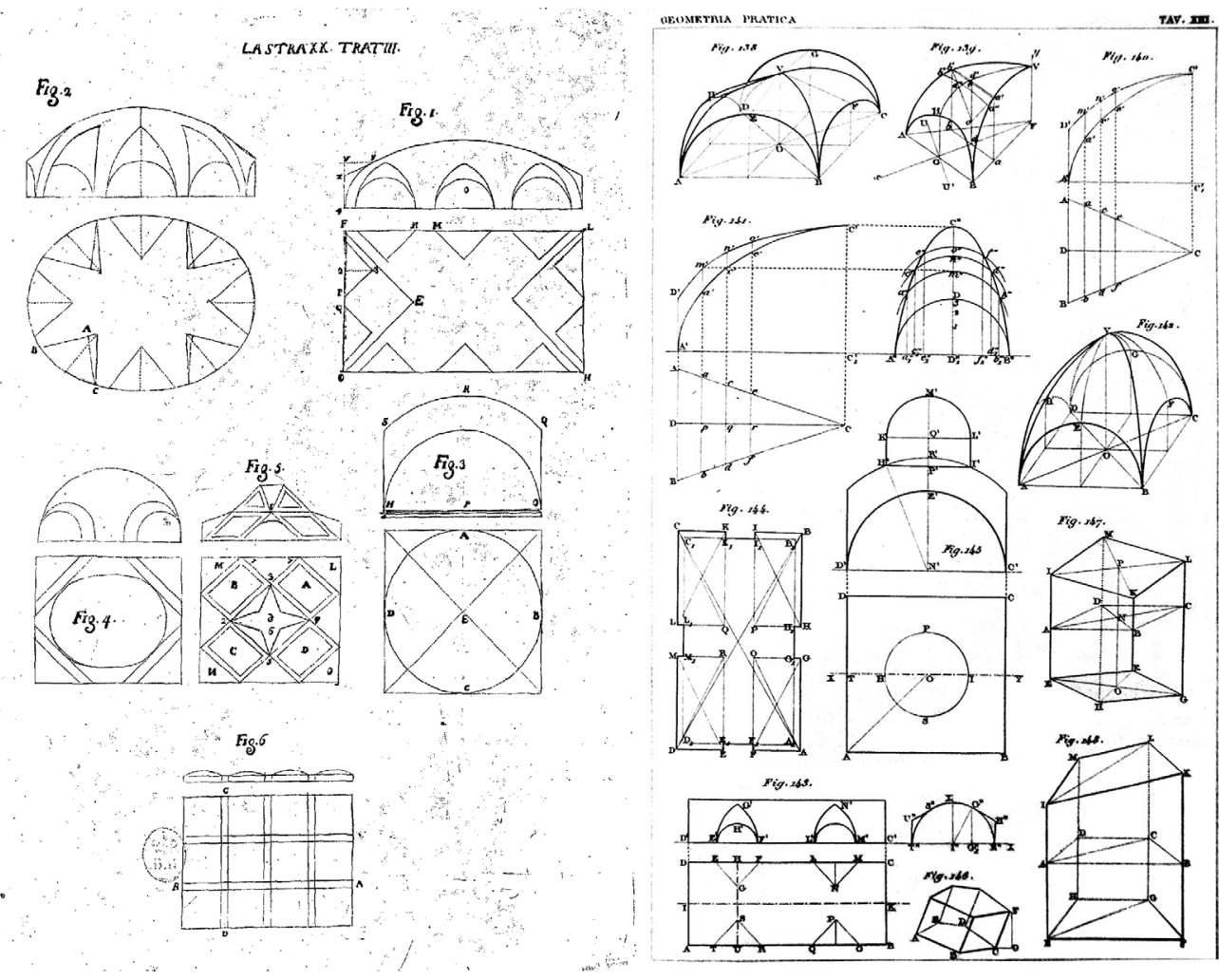
Fig. 4. Banded vault in the atrium of Palazzo Barolo (photo by Marco Vitali).

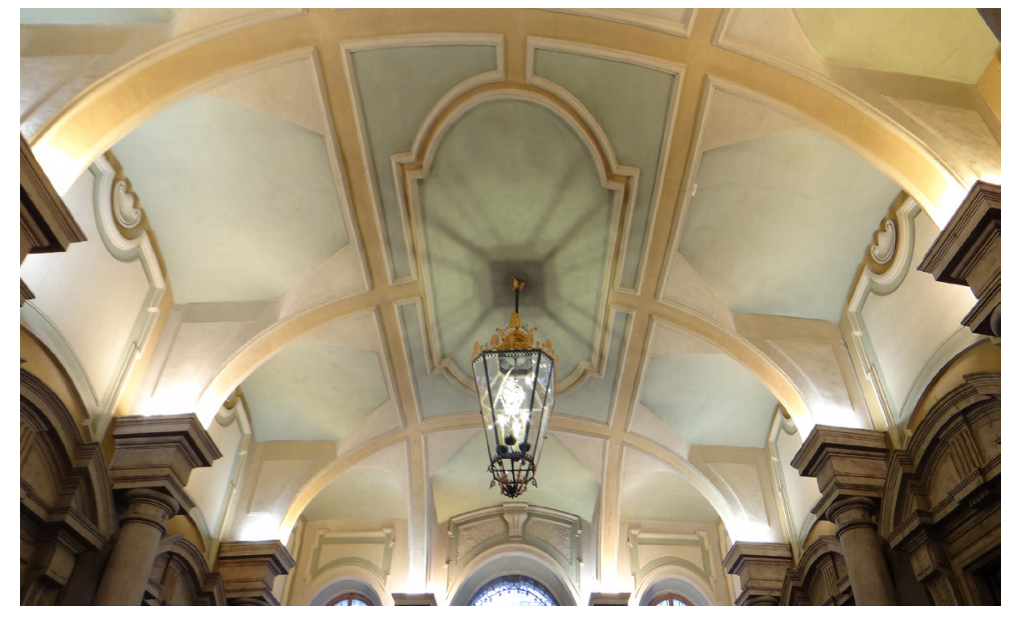

be surveyed. These will vary depending on the color, roughness and reflectance of the surface [Pfeifer et al. 2008, p. 330]. Another factor that influences the results is the distance at which the scanner is positioned, since the greater the distance between the station and the surface to be detected, the lower the return intensity [Mechelke, Kersten, Lindstaedt 2007, p. 320]. All these factors are usually present in cases of vaulted surfaces and therefore it is necessary to use a device with the right characteristics. For this study we used the Focus- I30-3D scanner by Faro that allows to assign to each point its color. After the scan, in fact, it takes a series of

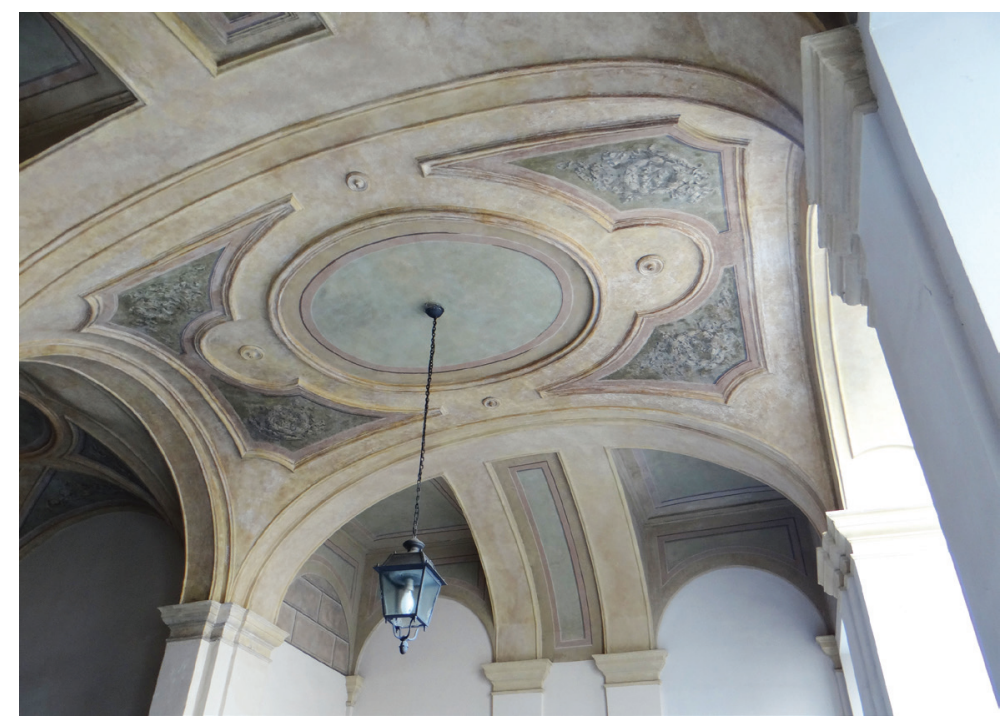

photographs that will be used to implement the color in the point cloud. Also the acquisition distance is adequate, because with this scanner it is possible to obtain a good density of points up to distances of $50 \mathrm{~m}$.

An important aspect to be considered is the angle of incidence of the laser, which in the case of the vaults varies along the entire surface. To solve this problem, scanning stations with different angles of incidence have been set up and arranged close enough to allow the data to overlap in order to obtain more reliable results. On the other hand, banded vaults have blind 


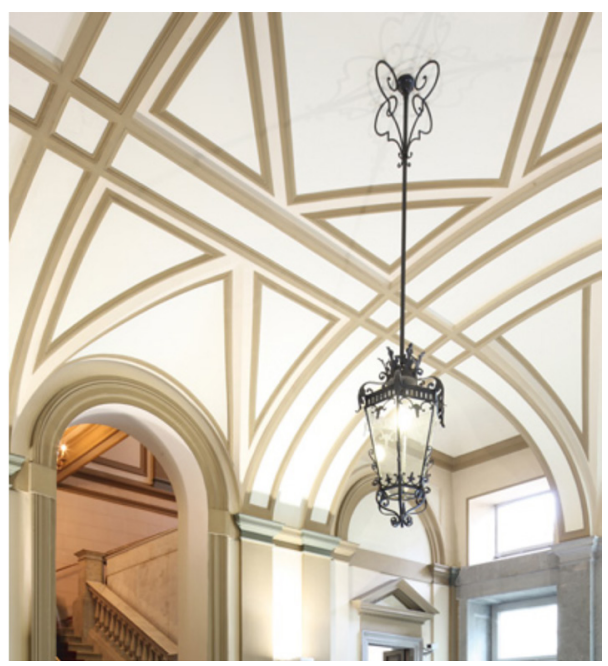

areas due to the shadows of the arches that divide the vault. In these cases, it is necessary to locate as many stations as there are portions of the vaulted system. All this requires previous programming of the survey campaign that guarantees the scanning of all the surfaces with a sufficient density of points and the necessary overlap to obtain rigorous results (fig. 8). The point cloud treatment was carried out with the program associated with the scanner brand, Scene (version 19), which provides fast and optimal results. (M.C.L.G.)
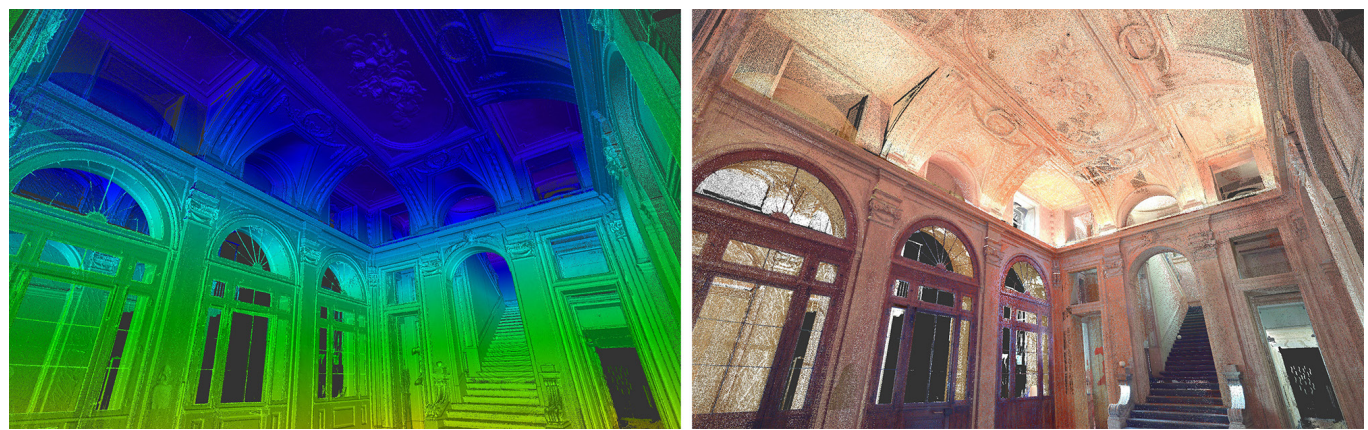

\section{Two and three-dimensional digital modeling between design and construction}

The methodologies of graphic representation and three-dimensional modeling of the vaulted systems developed in previous researches [Spallone, Vitali 2017] have been updated and modified according to the new metric survey techniques and the different ideal shape of the banded system.

The two main graphic products consist of: 1:50 scale plan and sections of the entire space, that are the outcome of the metric survey and interpretative analysis of the atria, and three-dimensional digital models, which can be linked to the shape design phase of the vaulted system, guided by references to coeval architectural literature and archival sources. Two-dimensional drawings now use the horizontal and vertical sections of the point cloud 
Fig. 8. Schematic diagram of the scanning process for the vaulted system in the atrium of Palazzo Coardi di Carpenetto (drawing by María Concepción López González). obtained by laser scanning as a basis for drafting. The selection of the cutting planes and the reference planes of the point cloud aimed to construct the most significant vertical sections is a conceptually complex operation that forces the drawer to move or rotate the section plane in order to intersect the most significant elements, such as the keystones of each vault, and to avoid foreshortenings in the elevations behind the cutting plane.

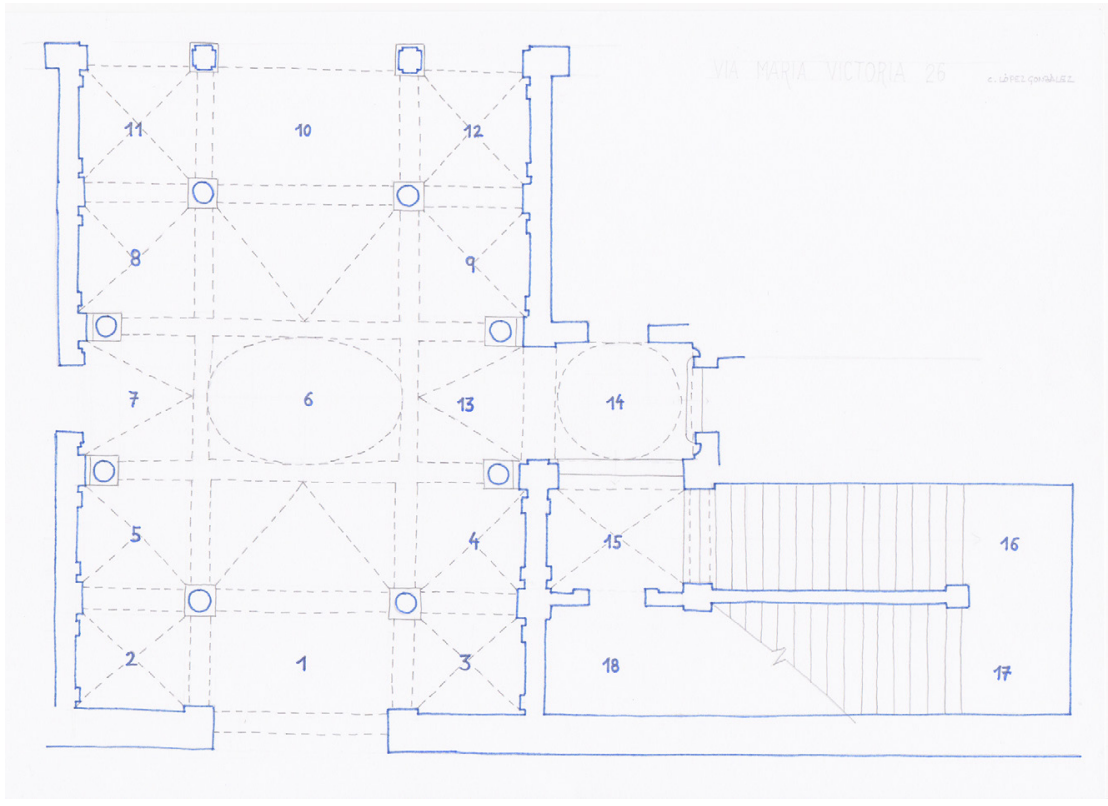

The workflow from point cloud to vector drawing involves additional issues related to the need to identify sequences of points that trace geometrically significant elements: edges, intersections between surfaces, impost planes and keystones. The reduction scale chosen for the drawings may suggest the minimum distance for the selection of points, but this is not sufficient when faced with historical architecture featured by architectural orders and decorative apparatus whose rigorous drawing guarantees the recognition and correct interpretation. As far as the reconstructive digital modelling of the design idea is concerned, it is necessary to restore the symmetries and bring the cross-sections back to elementary geometries.

The method of analysis, decomposition, and recomposition is based on Guarini's rules about the "way of drawing the vaults" [Guarini 1737, p. 188], which outlines a sequence, from the partition of the plans by means of bands, to the filling of the free fields with autonomous small vaults.

Not in all the cases analyzed, however, the vaults are geometrically independent of the arches that delimit them (fig. 9). In this case, the arches can be thought of as the result of a shell-like
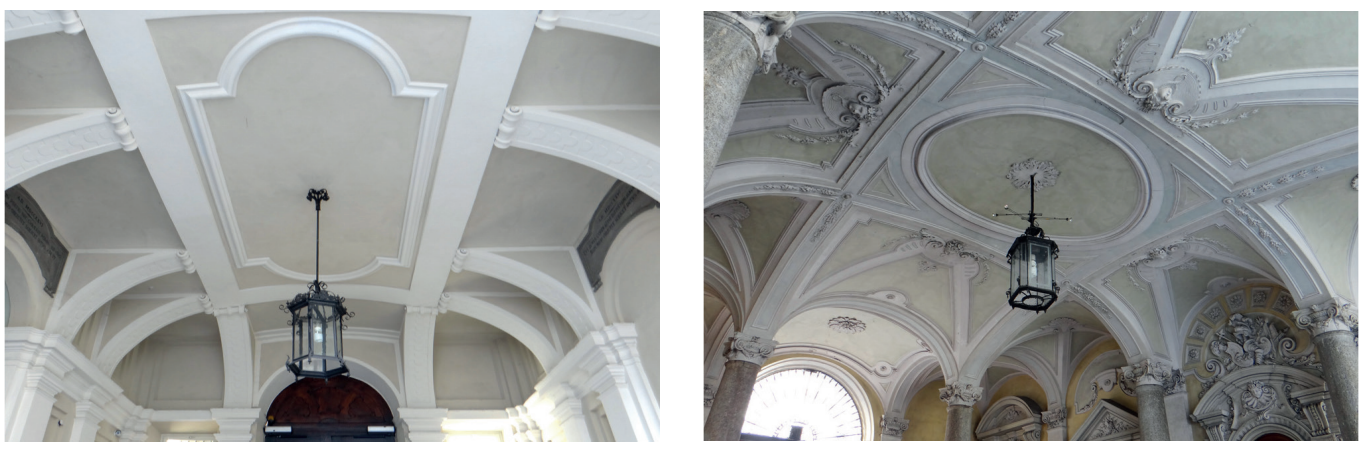

Fig. 9. Banded vault with independent small vault in the atrium of Palazzo Martini di Cigala (photo di Marco Vitali).

Fig. 10. Banded vault generated by a shell-like surface in the atrium of Palazzo Coardi di Carpenetto (photo di Marco Vitali). 
Fig. I I. Decomposition of interpretative models of banded vaults with independent small vaults: Palazzo Martini di Cigala (digital modeling by Roberta Spallone).

Fig. 12. Decomposition of interpretative models of banded vaults generated by a shell-like surface: Palazzo Coard di Carpenetto (digital modeling by Marco Vitali).
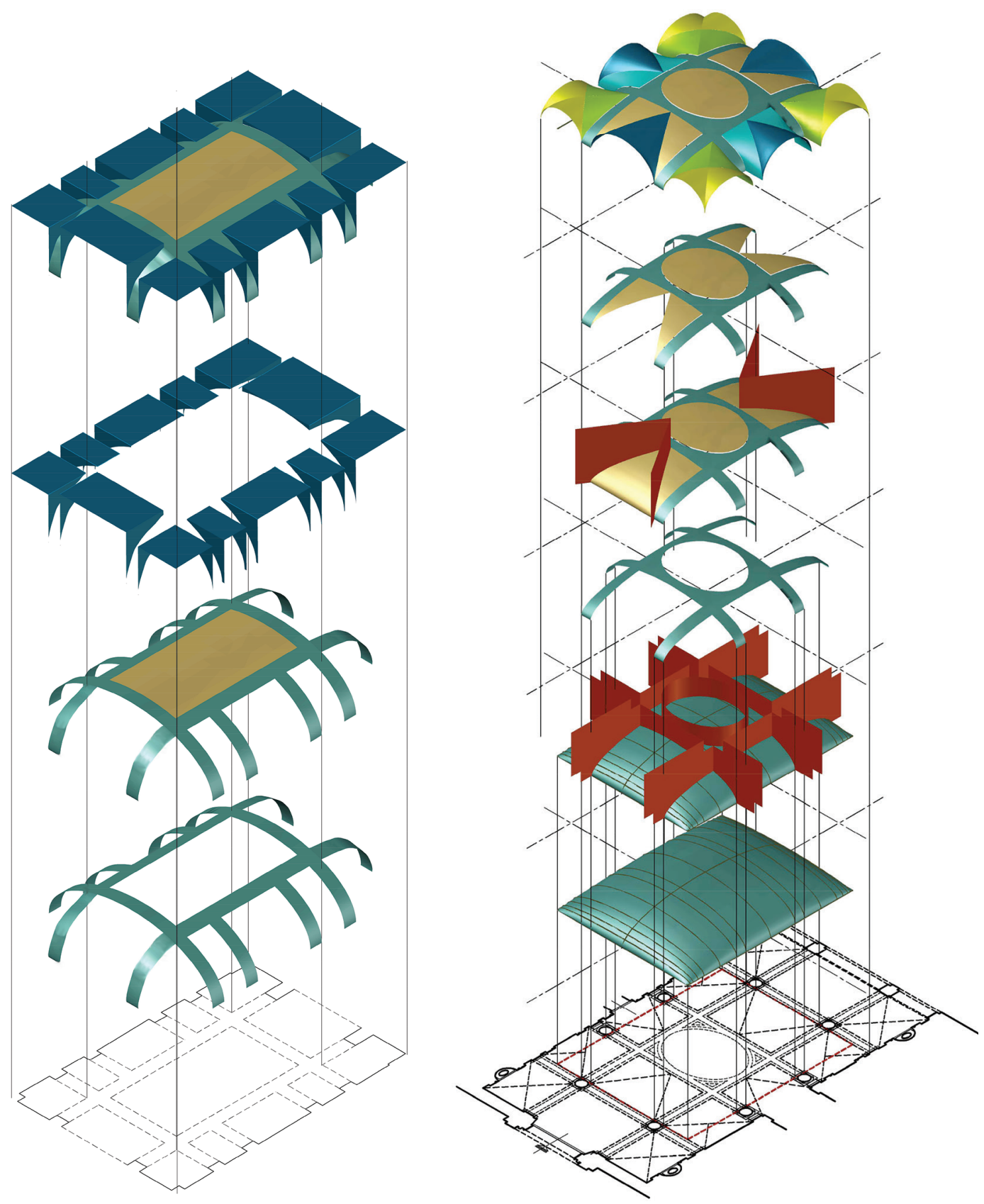
vault cut, whose surface is preserved, generally at least in the central field of the vault (fig. 10). These arches, instead of cylindrical or truncated cone shaped, as in the case of banded vaults with independent small vaults, assume curved and continuously variable longitudinal and transverse sections. The decomposition of the models, in the first case starts from the partition arches of the plan, followed by the completions with the small vaults (fig. II). In the second case, the main shell-like vault is cut with pairs of parallel planes, to generate the arches, while some portions of it are kept and the free fields, often at the corners, are completed by independent small vaults (fig. I2). (R.S.).

\section{Conclusions}

This contribution outlines the methodological framework developed for the metric survey and the processing of cognitive data in the research about banded vaulted systems in the baroque Turin.

The integration between the technique of metric survey by laser scanning with two-dimensional modelling, referring to the architectures analyzed in their real shape, and with three-dimensional modelling, related to the geometric reference models aimed at the philological reconstruction of the design idea, involves, as we have seen, the definition of new working criteria, aimed at optimizing the use of data. These procedures give rise to new opportunities for research, such as comparison (metric, but even more interesting, geometric) through the superimposition of ideal design models and point clouds. The deviations between the two digital products will not only reveal the deformations, collapses and transformations that are part of the very life of the building, but, above all, will provide new ideas for the hypotheses on the adaptations, the centering, and laying techniques developed on site, i.e. they will contribute to the understanding of the relationship between ideation and construction. Finally, the analysis and comparison of the vaulted systems surveyed, which are to be collected in a monographic volume, will make it possible to highlight shaping models and variations on the theme.

\section{Notes}

[I] This research is the result of the joint work of the three authors. The paragraphs An international project for the analysis and preservation of the architectural heritage and Conclusions have been drafted jointly, the paragraph Banded vaults between architectural literature and realizations by Marco Vitali, the paragraph TLS survey methods applied to vaulted systems by María Concepción López González, the paragraph Two and three-dimensional digital modeling between design and construction by Roberta Spallone.

[2] The reaserch group is composed by Arch. Giulia Bertola (research assistant at MODLab Arch, Politecnico di Torino), Fabrizio Natta (research fellow at DAD, Politecnico di Torino) e Francesca Ronco (research assistant at MODLab Design, Politecnico di Torino).

[3] These two atria in via Garibaldi are certainly subsequent to the straightening and widening of the street carried out from the end of the 1730s, at the time named Contrada di Dora Grossa, with the consequent reshaping of the buildings facing it.

\section{References}

Chevalley Giovanni (1924). Elementi di tecnica dell'architettura: materiali da costruzioni e grosse strutture. Torino: Pasta.

Curioni Giovanni (1868). Geometria pratica applicata all'arte del costruttore. Torino: Negro.

Guarino Guarini (1968). Architettura Civile. Introduzione di Nino Carboneri. Note e appendice a cura di Bianca Tavassi La Greca. Milano: II Polifilo (I ed. 1737).

Mechelke Klaus, Kersten Thomas P., Lindstaedt Maren (2007). Comparative investigations into the accuracy behaviour of the new generation of Terrestrial Laser Scanning systems. In Optical 3-D Measurement Techniques VIII, I (8I 3), pp. 3I 9-327.

Pfeifer Norbert, Dorninger Peter, Haring Alexander, Hongchao Fan (2008). Investigating terrestrial laser scanning intensity data: quality and functional relations. In Optical 3-D Measurement Techniques VIII, I (8 I 3), pp. 328-337. 
Piccoli Edoardo (1999). Strutture voltate composte nell'architettura civile piemontese del XVIII secolo: le volte planteriane. In Palladio, 3, 1999, pp. 87-100.

Piccoli Edoardo (200 I). Le strutture voltate nell'architettura civile a Torino (I 660- I 720). In Dardanello, Giuseppe (a cura di). Sperimentare l'architettura: Guarini, Juvarra, Alfieri, Borra e Vittone. Torino: Fondazione CRT, pp. 38-96.

Rodriguez Caballero Emilio, Chamizo Sonia, Afana Ashraf et al. (2012). Extracción automática de MDT a partir de datos procedentes de láser escáner (Espada). XI Reunión Nacional de Geomorfología Solsona. 20-24 de septiembre 20 I0. Santander: Ed. Universidad de Cantabria, pp. 263-266.

Ramos Luis, Marchamalo Miguel, Rejas, Juan Gregorio, Martínez R. (20I5). Aplicación del Láser Escáner Terrestre (TLS) a la modelización de estructuras: precisión, exactitud y diseño de la adquisición de datos en casos reales. In Informes de la Construcción, 67(538): e074, pp. I-9.

Spallone Roberta, Vitali Marco (20 17). Volte stellari e Planteriane negli atri barocchi in Torino. Star-shaped and Planterian Vaults in the Baroque Atria of Turin. Ariccia: Aracne.

Vitali Marco (20 | 8). Astrazione geometrica e modellazione tridimensionale per la definizione di una grammatica spaziale delle 'volte a fascioni' / Geometric abstraction and three-dimensional modeling for the definition of a spatial grammar of the 'a fascioni' vaults. In Salerno Rossella (a cura di). Rappresentazione/Materiale/lmmateriale | Drawing as (in)tangible representation. Atti del $40^{\circ}$ Convegno internazionale dei Docenti delle discipline della Rappresentazione. Milano 13- I5 settembre 20 I8. Roma: Gangemi editore, pp. 86I-870

Vitali Marco, Natta Fabrizio (2019). Digital Survey and 3D Geometric Interpretation of Complex Vaulted Systems. Palazzo Valperga Galleani di Barbaresco in Turin. In Metrology for Archaeology and Cultural Heritage (MetroArchaeo 20 I9) - Proceedings. Budapest: IMEKO, pp. 205-2I0.

\section{Authors}

Roberta Spallone, Politecnico di Torino, roberta.spallone@polito.it

María Concepción López González, Universitat Politècnica de València, mlopezg@ega.upv.es Marco Vitali, Politecnico di Torino, marco.vitali@polito.it

To cite this chapter. Spallone Roberta, López González María Concepción, Vitali Marco (2020). Integrazione di nuove tecnologie di rilevamento e modellazione per l'analisi dei sistemi voltati a fascioni/Integration of new survey and modeling technologies aimed at the analysis of banded vaulted systems. In Arena A., Arena M., Brandolino R.G., Colistra D., Ginex G., Mediati D., Nucifora S., Raffa P. (a cura di). Connettere. Un disegno per annodare e tessere. Atti del $42^{\circ}$ Convegno Internazionale dei Docenti delle Discipline della Rappresentazione/Connecting. Drawing for weaving relationships. Proceedings of the 42th International Conference of Representation Disciplines Teachers. Milano: FrancoAngeli, pp. 27I 6-2735. 